\section{Perlindungan Hukum Pemegang Hak Atas \\ Tanah Terhadap Objek Yang Sama (Studi Putusan Nomor putusan 55 Pdt. G.2007/PN.RAP)}

Oleh :

\section{Satria Braja Hariandja ${ }^{1}$}

Tim :

(Fijer Andreanto Siregar, Natanael Widianto Saragih, Veronica Br Tarigan) ${ }^{2}$

\section{Abstract}

The purpose of writing this article is to find out and to analyze whether the rights to land under the hands without being attended by witnesses can be justified by law and how legal protection of the holders of land rights is applied to the same object. The research method used in writing this article is normative research that uses a statue approach and conceptual approach. Based on the results of the study, the authors obtained answers to the problems; whether the above legal protection has fulfilled the basic elements Legal protection on land in fact it has a certificate on the same object so that mastery and ownership cause injustice. Responding to the things mentioned above, it is concluded that land is an inseparable part of human life and life so that land rights are human rights that legally contain control and ownership.

Keywords: Legal protection, Land rights, the same object

\section{Abstrak}

Tujuan dari penulisan jurnal ini adalah untuk mengetahui dan menganalisis apakah hak atas tanah dibawah tangan tanpa dihadiri oleh saksi dapat dibenarkan oleh hukum dan bagaimana bentuk perlindungan hukum pemegang hak atas tanah terhadap obyek yang sama. Metode penelitian yang digunakan dalam penulisan jurnal ini adalah penelitian normative yang menggunakan pendekatan perundang undangan (statue approach) dan pendekatan konsep (conceptual approach). Berdasarkan hasil penelitian, penulis memperoleh jawaban atas permasalahan yang ada, apakah

\footnotetext{
${ }^{1}$ Dosen Tetap Fakultas Hukum UNPRI Medan 2 Mahasiswa FH-UNPRI Medan
}

perlindungan hukum di atas telah memenuhi unsur pokok Perlindungan hukum atas tanah pada kenyataannya memiliki sertifikat pada obyek yang sama sehingga dalam hal penguasaan dan pemilikan menimbulkan ketidakadilan. Menyikapi hal-hal tersebut di atas, disimpulkan bahwa Tanah merupakan bagian yang tak terpisahkan dari hidup dan kehidupan manusia. Sehingga hak atas tanah merupakan hak asasi manusia yang secara hukum berisikan penguasaan dan pemilikan.

Kata kunci : Perlindungan hukum, Hak atas tanah, Obyek yang sama.

\section{PENDAHULUAN}

\section{A. Latar Belakang}

Tanah merupakan tempat tinggal, tempat manusia melakukan aktifitas sehari-hari dan juga menjadi sumber mata pencaharian bagi kalangan petani diwilayah pedesaan di seluruh Indonesia. Oleh karena pentingnya arti tanah bagi masyarakat Indonesia, maka banyak masyarakat yang berupaya untuk memilikihak atas tanah tersebut agar dapat dijadikan tempat mendirikan rumah kediaman, tempat bercocok tanam, tempat berusaha dengan mendirikan bangunan rumah tempat usaha atau bahkan melakukan pengalihan hak atas tanah tersebut. Tanah bisa dinilai sebagai suatu harta yang mempunyai sifat tetap dan dapat dicadangkan untuk kehidupan pada masa mendatang. Bahkan ada pendapat yang menyatakan bahwa tanah merupakan investasi besar untuk bekal harta masa depan penataan ulang struktur dan kebijakan pertanahan dalam hal penguasaan, kepemilikan, penggunaan dan pemanfaatan sumber daya agraria perlu dilakukan dengan komitmen politik pemerintah yang sungguhsungguh untuk memberikan arah dan dasar yang jelas dalam suatu kerangka pembaruan 
Media Komunikasi dan Informasi Hukum dan Masyarakat

agrarian yang berkeadilan, demokratis dan berkelanjutan. Hal ini mengingat begitu banyak dan kompleks permasalahan yang muncul di bidang pertanahan, apabila tidak ditangani dengan baik dan benar.

Karena begitu pentingnya tanah dalam kehidupan manusia, maka perlindungan akan hak tanah dimiliki oleh manusia menjadi penting dalam hal ini peran pemerintah menjadi penting karena Indonesia yang merupakan welfare state (negara kesejahteraan) harus melakukan segala untuk menyejahterakan masyarakat. Selain itu konsekuensi negara welfare state adalah negara bisa ikut campur dalam segala sendi kehidupan manusia termasuk di bidang pertanahan. Negara Kesatuan Republik Indonesia yang berdasarkan UUD 1945 adalah negara hukum (konstitusional) yang memberikan jaminan dan memberikan perlindungan atas hak-hak warga negara, antara lain hak warga negara untuk mendapatkan, mempunyai, dan menikmati hak milik. $^{3}$

Hak milik atas tanah sebagai salah satu jenis hak milik, sangat penting bagi negara, bangsa, dan rakyat Indonesia sebagai masyarakat agraria yang sedang membangun ke arah perkembangan industri dan lain-lain. Akan tetapi, tanah yang merupakan kehidupan pokok bagi manusia akan berhadapan dengan berbagai hal, antara lain :

1. Keterbatasan tanah, dalam jumlah maupun kualitas dibanding dengan kebutuhan yang harus dipenuhi.

2. Pergeseran pola hubungan antara pemilik tanah dan tanah sebagai akibat perubahanperubahan yang ditimbulkan oleh proses

3 Adrian Sutedi, Peralihan Hak Atas Tanah Dan Pendaftarannya, Sinar Grafika, Jakarta, 2009, hlm. 1 pembangunan dan perubahan-perubahan sosial pada umumnya.

3. Tanah di satu pihak telah tumbuh sebagai benda ekonomi yang sangat penting, pada lain pihak telah tumbuh sebagai bahan perniagaan dan objek spekulasi.

4. Tanah di satu pihak harus dipergunakan dan dimanfaatkan untuk sebesar-besarnya kesejahteraan rakyat lahir batin, adil dan merata, sementara dilain pihak harus dijaga kelestariannya.

UUPA sebagai peraturan dasar hanya memuat ketentuan-ketentuan hukum tanah yang baru dalam pokok-pokok dan garis-garis besarnya saja. Ketentuan-ketentuannya lebih lanjut akan diatur dalam berbagai peraturan pelaksanaan. Untuk mencegah terjadinya kekosongan hukum diadakanlah peraturan peralihan dalam Pasal 56,57 dan 58 UndangUndang Pokok Agraria, yang menetapkan bahwa selama peraturan-peraturan pelaksanaan yang bersangkutan belum ada, peraturan-peraturan yang lama, dengan syaratsyarat tertentu, untuk sementara masih tetap berlaku. Pasal 58 Undang-Undang Pokok Agraria merupakan peralihan yang bersifat umum. Pasal 56 Undang-Undang Pokok Agraria khusus mengenai peraturan-peraturan mengenai hak milik, sedang Pasal 57 UndangUndang Pokok Agraria mengenai ketentuanketentuan hipotek dan creditverband ${ }^{4}$. Peralihan hak atas tanah dapat melalui jual-beli, tukarmenukar, hibah ataupun karena pewarisan.

Hak milik sangat penting bagi manusia untuk dapat melaksanakan hidupnya di dunia. Semakin tinggi nilai hak milik atas suatu benda, semakin tinggi pula penghargaan yang diberikan terhadap benda tersebut. Tanah adalah salah

4 Pasal 56,57, Undang-Undang Pokok Agraria No. 5 Tahun 1960. 
Media Komunikasi dan Informasi Hukum dan Masyarakat

satu milik yang berharga bagi umat manusia, demikian pula bangsa Indonesia bagi orang Indonesia, tanah merupakan masalah yang paling pokok, dapat dikonstatir dari banyaknya perkara perdata maupun pidana yang diajukan ke pengadilan yaitu berkisar sengketa mengenai tanah. Sengketa tanah tersebut antara lain, menyangkut sengketa warisan, utang-piutang dengan tanah sebagai jaminan, sengketa tata usaha negara mengenai penerbitan sertifikat tanah, serta perbuatan melawan hukum lainnya. Berdasarkan banyaknya perkara yang menyangkut tanah, dapat dilihat bahwa tanah memegang peranan sentral dalam kehidupan dan perekonomian Indonesia. ${ }^{5}$

Bukti kepemilikan atau akta kepemilikan atas tanah berupa surat keterangan atau akta ganti rugi atau akta pelepasan hak atas tanah atau sertifikat hak milik, sangat penting untuk menghindari terjadinya sengketa tanah. Tetapi, walaupun seseorang sudah memiliki bukti kepemilikian atas tanah di kehidupan masyarakat sering terjadi sengketa tanah. Seperti halnya dalam pembahasan Jurnal ini, pada putusan Pengadilan Negeri Rantau Prapat Nomor putusan 55 Pdt. G.2007/PN.RAP terjadi sengketa tanah, yaitu keberadaan akta kepemilikan atas tanah yang saling bertumpang tindih atau akta kepemilikan ganda atas bidang tanah yang terjadi antara Darsono(Penggugat I), Paidi (Penggugat II), Sri Rezeki Siti Sukasih (Penggugat III), Harianto Kurniawan, S.H (Penggugat IV) sebagai yang memiliki sertifikat Camat Kualuh Huluh Kab. Labuhan Batu Utara Reg No.593/205/Pem/2008 tgl 8 Juli 2008 dengan para tergugat antara lain, Salmon Siregar sebagai Tergugat I yang memiliki Sertifikat Kepemilikan Tanah yang dikeluarkan oleh kantor Kepala Desa Air Hitam Kab.
Labuhan Batu Utara Nomor.593.2/KL/2012 Kepemilikan atas tanah yang saling tumpang tindih tersebut berdampak negatif seperti gandanya akta kepemilikan atau bukti kepemilikan atas tanah. Oleh karena itu, kepemilikan ganda atas tanah perlu dicegah dengan meminimalisirkan faktor-faktor penyebabnya. Apabila telah terjadi sengketa tanah, maka hakim harus memiliki pertimbangan-pertimbangan dalam putusan sesuai dengan Undang-Undang Pokok Agraria. Berdasarkan hal tersebut, peneliti akan melakukan penelitian dengan judul : PERLINDUNGAN HUKUM PEMEGANG HAK ATAS TANAH TERHADAP OBJEK YANG SAMA(Studi Putusan Nomor putusan 55 Pdt. G.2007/PN.RAP)

\section{B. Rumusan Masalah}

1. Bagaimana Ketentuan Hukum terhadap Kepemilikan Hak atas Tanah Menurut Undang-Undang Agraria Indonesia?

2. Bagaimana Ketentuan Sertifikat Sebagai Alat Bukti Dalam Penyelesaian Hak Atas Tanah

3. Bagaimana Pertimbangan Hakim ditinjau dari Pokok Perkara StudiPutusan 55 Pdt.G.2007/PN.RAP ?

\section{Metode Penelitian}

Penelitian ini akan mengkaji pokokpokok permasalahan sesuai dengan ruang lingkup dan identifikasi masalah sebagaimana telah disebutkan diatas melalui Penelitian bersifat yuridis normatif dengan melihat norma/aturan hukum tentang kepemilikan hak atas tanah. Bersifat deskriptif, yaitu mendeskriptifkan tentang kepemilikan hak atas

\footnotetext{
${ }^{5}$ Adrian Sutedi, Op.cit.,hlm 7-8.
} 
Media Komunikasi dan Informasi Hukum dan Masyarakat

tanah, proses peralihan hak atas tanah dan akta kepemilikan ganda atas tanah. ${ }^{6}$

\section{Hasil dan Pembahasan}

Untuk melaksanakan penelitian diperlukan sesuatu yang memberi arah dalam usaha memecahkan masalah dalam penelitian, dan berikut adalah arahan tersebut :

a. Akta

Akta adalah tulisan yang berisi tentang halhal yang sangat penting, dituangkan dalam sebuah surat yang dapat dijadikan sebagai pembuktian dan pada akhir dari akta akan di tandatangani oleh pihak yang bersangkutan. Pada Pasal 1867 KUH Perdata mengatakan bahwa pembuktian dengan tulisan dilakukan dengan tulisan otentik atau dengan tulisan di bawah tangan.

Menurut Pasal 1874 KUH Perdata, Akta dibawah tangan adalah "Surat atau tulisan yang dibuat oleh para pihak tidak melalui perantaraan pejabat yang berwenang (pejabat umum) untuk dijadikan alat bukti". Jadi, akta dibawah tangan semata-mata dibuat antara para pihak yang berkepentingan. ${ }^{7}$ Pasal 1868 KUH Perdata menjelaskan akta otentik ialah suatu akta yang dibuat dalam bentuk yang ditentukan undang-undang oleh atau dihadapan pejabat umum yang berwenang untuk itu di tempat akta itu dibuat.

b. Surat Keterangan Tanah dari Kepala Desa Adalah bukti surat keterangan tanah dari kepala desa sebagai bukti awal sebelum

\footnotetext{
${ }^{6}$ Soerjono Soekanto, Pengantar Penelitian Hukum, UI-PERSS, Jakarta, 1982, hlm 12.

Muhammad Syaifuddin, Hukum Kontak : Memahami Kontrak Dalam Perspektif Filsafat, Teori, Dogmatik, Dan Praktik Hukum (Seri Pengayaan Hukum Perikatan), CV. Mandar Maju, Bandung, 2012, hal 138.
}

bersertipikat. ${ }^{8}$ Surat keterangan tanah tersebut juga merupakan salah satu alat bukti tertulis untuk menunjukkan kepemilikan tanah guna kepentingan proses pendaftaran tanah. ${ }^{9}$

c. Peralihan hak atas tanah

Berpindahnya hak atas tanah dari pemegang (subjek) haknya kepada pihak lain karena suatu perbuatan hukum yang sengaja dilakukan dengan tujuan agar pihak lain tersebut memperoleh hak tersebut. Pihak yang mengalihkan/memindahkan hak harus berhak dan berwenang memindahkan hak, sedangkan pihak yang memperoleh hak harus memenuhi syarat sebagai pemegang hak atas tanah. ${ }^{10}$

d. Akta kepemilikan ganda atas tanah

Akta kepemilikan ganda atas ganda adalah surat atau bukti kepemilikan atas sebidang tanah yang lebih dari 1 akta, dimana hak kepemilikannya saling bertumpang tindih atau ganda antara pemilik akta yang satu dengan pemilik akta lainnya. Dengan kata lain, sebidang tanah dimiliki oleh 2 subjek hukum (orang) yang memiliki akta kepemilikan atas tanah tersebut.

${ }^{8}$ Miethra Tanjung, Skripsi : "Kedudukan Kepala Desa Mengeluarkan Surat Keterangan Tanah Dalam Transaksi Jual Beli Tanah Ditinjau Dari Peraturan Pemerintah Nomor 24 Tahun 1997 Tentang Pendaftaran Tanah" (Bengkulu : Universitas Bengkulu, 2014), hal 59

9 Klinik Hukum Online, "Surat Kepemilikan Tanah atau Surat Keterangan Riwayat Tanah", 2017 http://www.hukumonline.com/klinik/detail/t591d5 3cb37b54/surat-kepemilikan-tanah-atau-suratketerangan-riwayat-tanah, [05/06/2018]

10 Urip santoso, Pendaftaran Dan Peralihan Hak Atas Tanah, Kencana,Jakarta, 2011, hal 301-302 
Media Komunikasi dan Informasi Hukum dan Masyarakat

\section{A. Ketentuan Hukum terhadap Kepemilikan} Hak atas Tanah Menurut Undang-Undang Agraria Indonesia

1. Pegertian Hak Milik

Ketentuan mengenai Hak Milik dalam UUPA diatur dalam Pasal 16 ayat (1) hurufa yang mengatur bahwa hak hak atas sebagaimana dimaksud dalam Pasal 4 ayat (1) ${ }^{11}$ ialah salah satunya hak milik. Yang secara khusus diatur dalam Pasal 20 sampai denganPasal 27 UUPA.Pasal 20 UUPA memberikan pegertian hak milik sebagai hak turun-temurun, terkuat dan terpenuh yang dapat dipunyai orang atas tanah, dengan mengingat ketentuan dalam (Pasal 6). ${ }^{12}$ Yang mana dari definisi ini dapat dilihat bahwa sifat-sifat Hak Milik adalah ${ }^{13}$ :

1. Turun-Temurun. Artinya hak milik atas tanah dapat berlangsung terus selama pemiliknya masih hidup dan apabila pemiliknyameninggal dunia, maka hak miliknya dapat dilanjutkan olehahli warisnya sepanjang memenuhi syarat subyek hak milik.

2. Terkuat Artinya bahwa hak milik atas tanah tersebut yang paling kuat diantara hak-hak lain atas tanah.Tidak mempunyai batas

${ }^{11}$ Pasal 4 ayat (1) UUPA mengatur bahwa atas dasar hak menguasai dari negara sebagai yang dimaksud dalam Pasal 2 ditentukan adannya macam-macam hak atas permukaan bumi, yang disebut tanah, yang dapat diberikan kepada dan dipunyai oleh orang-orang, baik sendiri maupun bersamasama dengan orang lain serta badan-badan hukum. Sedangkan Pasal 2 mengatur terkait terkait hak menguasai negara yang didasarkan atas pertimbangan Pasal 33 ayat (3) UUD NRI 1945

${ }^{12}$ Kartini Muljadi dan Gunawan, 2008, Hak-Hak Atas Tanah, Jakarta: Kencana, hlm.29

${ }^{13}$ Aminuddin Salle, 2011, Buku Bahan Ajar: Hukum Agraria, Makassar Aspublihing, hlm. 10 waktu tertentu, mudah dipertahankan dari gangguan pihak lain, dan tidak mudah hapus.

3. Terpenuh Artinya hak milik atas tanah memberi wewenang kepada pemiliknya paling luas bila dibandingkan dengan hak atas tanah yang lain, dapat menjadi induk bagi hak atas tanah yang lain, dan penggunaan tanahnya lebih luas jika dibandingkan dengan hak atas tanah yang lain

2. Subyek Hak Milik

Penjelasan mengenai siapa saja subyek dari hak milik atau siapa saja yang boleh memiliki hak milik, ketentuannya dapat kita lihat dalam UUP Pada Pasal 21UUPA mengatur bahwa hanya warga negara Indonesia yang dapat mempunyai hak milik serta badan- badan hukum tertentu. Badan-badan hukum yang dapat mempunyai hak milik yaitu badan-badan hukum yang ditentukan dalam Peraturan Pemerintah No. 38 Tahun1963, ${ }^{14}$ yakni:

1. Bank-Bank yang didirikan oleh Negara;

2. Perkumpulan-perkumpulan koperasi pertanian yang didirikan berdasarkan UU no.79 Tahun 1958;

3. Badan- badan keagamaan dan badan badan social yang ditunjuk oleh Menteri Dalam Negeri setelah mendegar Menteri Agama dan Menteri Sosial. Artinya bahwa yang dapat mempunyai(subyek hak) tanah hak milik adalah:

1) Perseorangan Hanya warga negara Indonesia yang dapat mempunyai hak milik (Pasal 21 ayat (1) UUPA). Dimana berdasarkan hal diatas ditentukan bahwa perseorangan yang hanya

${ }^{14}$ Farida Patittingi, 2012, Dimensi Hukum Pulau-Pulau Kecil Di Indonesia, Yogyakarta, Rangkang Education, hlm.120 
Media Komunikasi dan Informasi Hukum dan Masyarakat

berkewarganegaraan Indonesia yang dapat mempunyai tanah hak milik.

2) Badan-badan hukum Pemerintah menetapkan badan-badan hukum -yang dapat mempunyai hak mllik dan syaratsyaratnya (Pasal 21 ayat (2) UUPA).

\section{Hak Pemegang Hak Milik}

Sebagaimana disebutkan diawal bahwa sifat-sifat daripada hak milik yang membedakannya dengan hak lainnya.Hak milik adalah hak turun-temurun, terkuat dan terpenuh yang dipunyai orang atas tanah.Berdasarkan hal ini maka kepada pemegang hak milik terdapat hak untuk mewariskan hak milik atas tanahnya kepada ahli warisnya serta terhadap hak miliknya pemegang hak milik dapat mengalihkan hak miliknya sebagai bagian dari sifat terkuat dan terpenuh sebagaimana sifat dari hak milik. Soedikno Mertokusumo, berpendapat bahwa hak yang melekat kepada pemegang hak milik ini dipersamakan dengan wewenang.Dimana wewenang yang dipunyai oleh pemegang hak atas tanah

terhadap tanahnya dibagi menjadi 2 , yaitu ${ }^{15}$ :

1) Wewenang Umum

Wewenang yang bersifat umum yaitu pemegang hak atas tanah mempunyai wewenang untuk menggunakan tanahnya, termasuk juga tubuh bumi dan air dan ruang yang ada diatasnya sekadar diperlukan untuk kepentingan yang langsung berhubungan dengan penggunaan tanah itu dalam batas-batas menurut UUPA dan peraturan-peraturan hukum lain yang lebih tinggi (Pasal 4 ayat (2) UUPA).

\footnotetext{
${ }^{15}$ Aminuddin Salle, Op.cit, hlm.106-107
}

2) Wewenang Khusus

Wewenang yang bersifat khusus yaitu pemegang hak atas tanah mempunyai wewenang untuk menggunakan tanahnya sesuai dengan macam hak atas tanahnya, misalnya wewenang pada tanah hak milik dapat untuk kepentingan pertanian dan atau mendirikan bangunan

4. Terjadinya Hak Milik

1) Berdasarkan Pasal 22 UUPA terjadinya hak milik adalah sebagai berikut: (1) Terjadinya hak milik menurut hukum adat diatur dengan Peraturan Pemerintah; (2) Selain menurut cara yang dimaksud dalam ayat (1) Pasal ini hak milik terjadi karena: Penetapan Pemerintah, menurut cara dan syarat-syarat yang ditetapkan dengan Peraturan Pemerintah. Hak atas tanah terjadi karena Penetapan Pemerintah yaitu hak atas tanah yang diproses melalui mekanisme pemberian hak atas tanah.

2) Ketentuan undang-undang.

Terjadinya hak milik menurut hukum adat dapat dilakukan dengan cara membuka tanah baru, contohnya pembukaan tanah ulayat.Peraturan Menteri Dalam Negeri Nomor 6 tahun 1972 memberikan kewenangan kepada para Bupati/Walikotamadya (sekarang Kepala Kantor Pertanahan) dan Camat/Kepala Kecamatan untuk memberi keputusan mengenai permohonan izin membuka tanah. Akan tetapi dengan surat tertanggal 22 Mei 1984 Nomor 593/570/SJ diinstruksikan oleh Menteri Dalam Negeri kepada para Camat untuk tidak menggunakan kewenangan tersebut (Boediharsono,2008:326). Penetapan Pemerintah dituangkan dalam Surat 
Media Komunikasi dan Informasi Hukum dan Masyarakat

Keputusan Pemberian Hak Atas Tanah, yang diatur sebagai berikut:

1) PMA/KBPN No.3 Tahun 1999 tentang Pelimpahan Kewenangan Dan Pembatalan Keputusan Pemberian Hak Atas Tanah Negara

2) $P M A / K B P N$ No.9 Tahun 1999 tentang Tata Cara Pemberian Dan Pembatalan Hak Atas Tanah Negara Dan Hak Pengelolaan.

5. Hak-Hak Atas Tanah Menurut UUPA

Macam-macam hak atas tanah dimuat dalam pasal 16 Jo 53 UUPA, yang dikelompokkkan menjadi 3 bidang,yaitu:

1. Hak atas tanah yang bersifat tetap Hak-hak atas tanah ini akan tetap ada selama UUPA masih berlaku atau belum dicabut dengan undang-undang yang baru. Contoh: HM.HGU, HGB, HP, Hak Sewa untuk Bangunan dan Hak Memungut Hasil Hutan.

2. Hak atas tanahyang akanditetapkan dengan undang-undang Hak atas tanah yang akan lahir kemudian, yang akan ditetapkan dengan undang-undang.

3. Hak atas tanahyang bersifat sementara Hakatas tanahini sifatnya sementara,dalam waktu yang singkat akan dihapus dikarenakan mengandung sifat-sifat pemerasan,Dan bertentangan dengan jiwa UUPA $^{16}$

\section{B. Ketentuan Sertifikat Sebagai Alat Bukti}

\section{Dalam Penyelesaian Hak Atas Tanah}

\section{A. Alat Bukti Hak Atas Tanah}

Untuk membuktikan seseorang atau suatu badan hukum sebagai empunya suatu bidang tanah maka perlu alat bukti. Dalam Pasal 19 ayat (2) huruf c UUPA dan Pasal 32 ayat (1) PP 24/1997 ditentukan bahwa sertifikat berfungsi sebagai alat bukti hak atas tanah. Sertifikat sebagai alat bukti hak atas tanah diterbitkan oleh Kantor Pertanahan Kabupaten/Kota melalui suatu proses

${ }^{16}$ Wantijk Saleh, Hak Anda Atas Tanah, Jakarta, Ghalia Indonesia 1982, hIm 15. pendaftaran tanah, karena itu apabila suatu bidang tanahbelum dilaksanakan pendaftaran tanahnya maka atas bidang tanah tersebut tidak mempunyai sertifikat. Salah satu alasan penerbitan PP 24/1997 bahwa ketentuan hukum yang dijadikan dasar pelaksanaan pendaftaran tanah dirasakan belum cukup memberikan kemungkinan untuk terlaksananya pendaftaran tanah dalam waktu yang singkat dengan hasil yang memuaskan, hal ini didasarkan pada kenyataan bahwa pendaftaran tanah yang diselenggarakan berdasarkan Peraturan Pemerintah Nomor 10 tahun 1961 selama 35 tahun belum cukup memberikan hasil yang memuaskan. Dari 55 juta bidang tanah hak yang memenuhi syarat untuk didaftarkan, baru lebih kurang 16,3 juta bidang yang sudah didaftar.1 Pada tahun 2006 Badan Pertanahan Nasional (BPN) menyebutkan bahwa sejak UUPA diundangkan tahun 1960 sampai tahun2006 telah diterbitkan 33,74 juta sertifikat tanah atau sekitar $36 \%$ dari jumlah bidang tanah yang perlu disertifikat di luar kawasan hutan. ${ }^{17}$

Pasal 164 HIR/284 RBg dan Pasal 1866 KUH Perdata menyebutkan bahwa alat bukti dalam perkara perdata terdiri atas; bukti tertulis/surat, bukti saksi, persangkaanpersangkaan, pengakuan dan sumpah. Alat bukti tertulis atau surat ialah segala sesuatu yang memuat tanda-tanda bacaan yang dimaksudkan untuk mencurahkan isi hati atau untuk menyampaikan buah pikiran seseorang dan dipergunakan sebagai pembuktian.Dalam membuktikan adanya sesuatu peristiwa atau

17 Risnarto, Dampak Sertipikasi Tanah Terhadap Pasar Tanah dan Kepemilikan Tanah Skala Kecil, Makalah disajikan pada Seminar Nasional Land and Household Economy 1970200, Changing Roads for Poverty Reduction. PSEKP and UNESCAP-CAPSA, Bogor.Indonesia, tanggal 25 Juni 2007. 
Media Komunikasi dan Informasi Hukum dan Masyarakat

adanya sesuatu hak pertama-tama digunakan bukti tulisan. Apabila bukti tulisan tidak ada atau tidak cukup maka digunakan bukti saksi, apabila bukti saksi tidak cukup maka digunakan bukti persangkaan, jika bukti tulisan ditambah bukti saksi dan bukti persangkaan juga belum cukup maka ditambah lagi dengan bukti pengakuan. Jikalau dengan bukti-bukti tersebut juga belum mencukupi maka ditambah lagi dengan bukti sumpah. ${ }^{18}$ Dalam hukum pembuktian dikenal tiga jenis surat, yaitu akta otentik, akta dibawah tangan dan surat bukan akta. Akta otentik merupakan surat yang dibikin dengan maksud untuk dijadikan bukti oleh atau dimuka seorang pejabat umum yang berkuasa untuk itu. Berdasarkan Pasal 1 angka 20 PP 24/1997, sertifikat adalah surat tanda bukti hak sebagaimana dimaksud dalam Pasal 19 ayat (2) huruf c UUPA untuk hak atas tanah, hak pengelolaan, tanah wakaf, hak milik atas satuan rumah susun dan hak tanggungan yang masingmasing sudah dbukukan dalam buku tanah yang bersangkutan. Secara teknis batasan tentang sertifikat pernah dimuatdalam PP Nomor 10 Tahun 1961 yang menyebutkan bahwa sertifikat adalah salinan buku tanah dan surat ukur yang dijilid menjadi satu dan diberikan sampul.

Sertifikat diterbitkan BPN yang didalamnya memuat data fisik dan data yuridis suatu bidang tanah tertentu. Data fisik berkenaan dengan letak, batas dan luas bidang tanah. Sedangkan data yuridis berkenaan dengan subyek hak, alas hak dan pembebanan hak atas tanah. Data tersebut diperoleh dari pemohon sertifikat dan pemeriksaan oleh BPN melalui proses pendaftaran tanah. Karena itu dalam kaitannya dengan alat-alat bukti dalam

18 Teguh Samudra, Hukum Pembuktian Dalam Acara Perdata, Alumni, Bandung, 2004, hlm. 9. proses peradilan perdata sebagaimana dimaksud dalam Pasal 164 HIR/284 RBg dan Pasal 1866 KUH Perdata maka sertifikat berstatus sebagai bukti surat yang berkualifikasi sebagai akta otentik.

Berdasarkan uraian di atas dapat dipahami bahwa dalam hal suatu bidang tanah tidak atau belum mempunyai sertifikat, maka dapat dibuktikan dengan bukti-bukti lainnya sebagaimana ditentukan dalam ketentuan perundang-undangan. Bukti-bukti lainnya tersebut sebagaimana diatur dalam Pasal 164 HIR/284 RBg, dan Pasal 1866 KUH Perdata serta Pasal 23 dan Pasal 24 PP 24/1997 yang mengatur mengenai pembuktian hak atas tanah untuk keperluan pendaftaran hak atas tanah.

Dalam Pasal 23 PP 24/1997 disebutkan bahwa untuk keperluan pendaftaran hak atas tanah terhadap hak-hak atas tanah yang lahir setelah berlakunya UUPA dapat dibuktikan dengan; (a) penetapan pemberian hak (Surat Keputusan Pemberian Hak) atas tanah Negara atau atas tanah hak pengelolaan dari pejabat yang berwenang, (b) akta pemberian Hak Pakai atau Hak Guna Bangunan atas tanah Hak Milik dari PPAT (c) akta ikrar akaf, (d) akta pemisahan hak milik atas satuan rumah susun, dan (e) akta pemberian hak tanggungan.

Terkait dengan kekuatan pembuktian sertifikat hak atas tanah terdapat istilah tersendiri dalam ketentuan perundangundangan pertanahan, antara lain sebagaimana ditentukan dalam Pasal 19 ayat (2) huruf $\mathrm{C}$ UUPA yang menyebutkan bahwa kegiatan pendaftaran tanah meliputi; "Pemberian suratsurat tanda bukti hak, yang berlaku sebagai alat pembuktian yang kuat". Demikian juga halnya Pasal 32 ayat (1) PP 24/1997 yang menyebutkan; "sertifikat merupakan surat tanda bukti hak yang berlaku sebagai alat pembuktian 
Media Komunikasi dan Informasi Hukum dan Masyarakat

yang kuat mengenai data fisik dan data yuridis yang termuat di dalamnya, sepanjang data fisik dan data yuridis tersebut sesuai dengan data yang ada dalam surat ukur dan buku tanah hak yang bersangkutan".

\section{B. KEKUATAN BUKTI SERTIFIKAT}

Salah satu fungsi akta adalah sebagai alat pembuktian. Sebagai alat pembuktian akta dibedakan kedalam tiga macam kekuatan pembuktian, yaitu: kekuatan pembuktian lahir, kekuatan pembuktian formal dan kekuatan pembuktian material. ${ }^{19}$ Kekuatan bukti lahir merupakan kekuatan bukti yang didasarkan atas keadaan lahir bahwa suatu surat yang kelihatannya seperti akta dianggap/diterima sebagai suatu akta dan harus diperlakuakn sebagai akta sepanjang tidak terbukti kebalikannya. Sedangkan kekuatan bukti formal merupakan kekuatan bukti yang didasarkan atas benar atau tidaknya pernyataan dalam akta bahwa penandatangan akta menerangkan apa yang tercantum dalam akta. Sementara itu kekuatan pembuktian material merupakan kekuatan pembuktian yang didasarkan atas benar atau tidaknya isi dari pernyataan bahwa penandatangan menyatakan bahwa peristiwa hukum yang dinyatakan dalam akta itu benarbenar telah terjadi.

Sertifikat yang mempunyai kedudukan sebagai akta otentik mempunyai kekuatan pembuktian lahir, formil dan materil dan berdasarkan Pasal 165 HIR bahwa akta otentik mempunyai kekuatan yang sempurna. Artinya apa yang tercantum didalamnya harus diterima sebagai suatu yang benar selama tidak ada pihak yang dapat membuktikan sebaliknya.

19 Teguh Samudra, Ibid, hlm. 47-49
Lebih lanjut dalam Penjelasan Pasal 32 ayat (1)) PP 24/1997 disebutkan bahwa sertifikat merupakan tanda bukti yang kuat, dalam arti bahwa selama tidak dapat dibuktikan sebaliknya data fisik dan data yuridis yang tercantum di dalamnya harus diterima sebagai data yang benar. Karena itu selama tidak dapat dibuktikan sebaliknya, data fisik dan data yuridis yang tercantum dalam sertifikat harus diterima sebagai data yang benar, baik dalam Lakukan perbuatan hukum sehari hari maupun dalam berperkara di pengadilan. ${ }^{20}$

Berdasarkan PP 10/1961 bahwa kapanpun seseorang atau badan hukum dapat mengajukan gugatan terhadap suatu sertifikat tetapi berdasarkan PP 24/1997, yang juga telah mencabut dan menyatakan tidak berlaku PP 10/1961, bahwa gugatan terhadap suatu sertifikat tidak lagi dapat diajukan apabila telah lewat waktu tertentu dan telah memenuhi persyaratan sebagaimana ditentukan dalam Pasal 32 ayat (2). Pasal 32 ayat (2) PP 24/1997 menyebutkan: Dalam hal atas suatu bidang tanah sudah diterbitkan sertifikat secara sah atas nama orang atau badan hukum yang memperoleh tanah tersebut dengan itikad baik dan secara nyata menguasainya, maka pihak lain yang merasa mempunyai hak atas tanah itu tidak dapat lagi menuntut pelaksanaan hak tersebut apabila dalam waktu 5 (lima) tahun sejak diterbitkannya sertifikat itu tidak mengajukan keberatan secara tertulis kepada pemegang sertifikat dan Kepala Kantor Pertanahan yang bersangkutan ataupun tidak mengajukan gugatan ke Pengadilan mengenai penguasaan tanah atau penerbitan sertifikat tersebut.

20 Irawan Soerodjo, Kepastian Hukum Hak Atas Tanah Di Indonesia, Arkola, Surabaya, 2003, hlm. 110 
Media Komunikasi dan Informasi Hukum dan Masyarakat

Oleh karena hukum tanah Indonesia berdasarkan pada hukum adat maka untuk mengatasi kelemahan tersebut menggunakan lembaga "rechtsverwerking". Berdasarkan ketentuan tersbut dapat dipahami bahwa batas waktu 5 (lima) tahun itu berlaku apabila memenuhi 3 (tiga) persyaratan, yaitu;

1. pelaksanaan pendaftaran tanah yang melahirkan sertifikat tersebut dilakukan secara sah, artinya sesuai dengan ketentuan perundang-undangan yang berlaku, sebagai contoh bahwa salah satu tahapan dalam pelaksanaan pendaftaran tanah adalah dilakukan pengumuman terhadap data tanah yang telah diteliti sebelum dilakukan pembukuan hak atas tanah. Apabila pengumuman tidak dilakukan atau dilakukan tidak sesuai dengan aturan atau menyimpang dari tujuan diadakan pengumuman maka hal itu dapat dikategorikan sebagai cacat hukum dalam proses pensertifikatan;

2. penguasaan tanah oleh pemohon atau penerusnya dilakukan dengan itikad baik, hal ini tentu ada ukuran-ukuran dalam hukum mengenai itikad baik tersebut; dan

3. tanah tersebut dikuasai secara nyata oleh pemohon, hal ini berarti tidak cukup penguasaan secara hukum saja.

Dengan demikian apabila ketiga persyaratan tersebut tidak dipenuhi secara kumulatif maka batasan waktu 5 (lima) tahun tersebut tidak dapat diterapkan. Karena pengaturannya masih dalam bentuk Peraturan Pemerintah maka hakimlah dalam penerapan Pasal 32 ayat (2) PP 24/1997 terhadap kasuskasus konkrit yang akan mempertimbangkan terpenuhinya syarat-syarat bagi penerapannya sebagaimana halnya penerapan lembaga "rechtsverwerking" pada tanah-tanah adat. Hakimlah yang menimbang berat ringannya bobot kepentingan para pihak yang bersengketa dan dalam rangka pembaharuan hukum tanah nasional maka ketentuan tersebut perlu diatur dalam bentuk undang-undang. ${ }^{21}$

Penyataan bahwa suatu sertifikat tidak mempunyai kekuatan hukum merupakan kewenangan pengadilan sedangkan pembatalan sertifikat merupakan kewenangan BPN. Berdasarkan Pasal 3 Peraturan Presiden Nomor 10 Tahun 2006 tentang Badan Pertanahan Nasional dan Pasal 13 Peraturan Menteri Negara Agraria/Kepala BPN Nomor 3 Tahun 1999 tentang Pelimpahan Kewenangan Pemberian dan Pembatalan Keputusan Pemberian Hak Atas Tanah Negara, bahwa Menteri Negara Agraria/Kepala BPN berwenang membatalkan keputusan pemberian hak atas tanah. Lebih lanjut dalam Pasal 104 Peraturan Menteri Negara Agraria/ Kepala BPN Nomor 9 Tahun 1999 tentang Tata Cara Pemberian dan Pembatalan Hak Atas Tanah Negara dan Hak Pengelolaan, disebutkan bahwa pembatalan keputusan pemberian dan sertifikat hak atas tanah diterbitkan karena dua hal, yaitu (1) karena terdapat cacat hukum administratif dalam penerbitan keputusan pemberian dan/atau sertifikat hak atas tanahnya, atau (2) karena melaksanakan putusan pengadilan yang telah memperoleh kekuatan hukum tetap.

\section{Pertimbangan Hakim ditinjau dari Pokok Perkara Studi Putusan 55 Pdt.G.2007/PN.RAP}

21 Boedi Harsono, Hukum Agraria Indonesia, Sejarah Pembentukan UndangUndang Pokok Agraria, Isi dan Pelaksanaannya,cetakan kesepuluh, Djambatan, Jakarta, 2005, hlm. 482. 
Media Komunikasi dan Informasi Hukum dan Masyarakat

\section{A. Pokok Perkara}

Berdasarkan pertimbangan hukum dalam pokok perkara mengenai bagian tanah yang menjadi sengketa, adalah sebagai berikut :

1. Menimbang, bahwa dari rangkaian asalusul perolehan tanah Penggugat I Darsono, Penggugat II Paidi, Penggugat III Sri Rezeki Siti Sukasih dan Pnggugat IV Harianto Kurniawan, S.H mempunyai hubungan kekerabatan pesaudaraan dan terlihat jelas berasal dari orang yang sama yaitu : Dusun Lubuk Pinang Desa Sukarame Kecamatan Kualuh Hulu Kabupaten Labuhanbatu Utara, Menimbang, bahwa keseluruhan tanah Dusun Lubuk Pinang adalah didasarkan kepada surat keterangan Tanah Nomor : 539/180/PN/2008 tanggal 7 Juli 2008 yang dikeluarkan oleh Pj. Kepala Desa Sukarame dan telah terdaftar di kantor kualuh hulu kabupaten Labuhan Batu Reg. Nomor 593/203/Pem/2008 tanggal 8 juli 2008, beserta lengkap dengan lampiran asal muasal tanah maka luas tanah milik DARSONO dkk seluas 28 Hektar.

2. Menimbang, bahwa keseluruhan tanah Dusun Lubuk Pinang adalah didasarkan kepada surat keterangan Tanah Nomor : 539/180/PN/2008 tanggal 7 Juli 2008 yang dikeluarkan oleh $\mathrm{Pj}$. Kepala Desa Sukarame dan telah terdaftar di kantor kualuh hulu kabupaten Labuhan Batu Reg. Nomor 593/203/Pem/2008 tanggal 8 juli 2008, beserta lengkap dengan lampiran asal muasal tanah maka luas tanah milik DARSONO (Milik Penggugat Dkk) Dengan batas-batas sebagai berikut
- Sebelah Utara : 300 m berbatas dengan tanah Paidi

- Sebelah Timur : 150 m berbatas dengan tanah Darsono

- Sebelah selatan : $300 \mathrm{~m}$ berbatas dengan tanah Sri Rezeki Siti Sukasih

- Sebelah barat : $150 \mathrm{~m}$ berbatas dengan tanah Suwardi

3. Menimbang, Bahwa sekitar tahun 2008 tanpa seizin para penggugat, tergugat telah menguasai dan mengusahai sebahagian tanah, tanah yang di maksud seluas lebih kurang 28 Hektar hingga saat sekarang

4. Menimbang, bahwa Fotocopy surat keterangan Tanah Nomor : 539/182/Pem/2008 tanggal 7 Juli 2008 yang dikeluarkan oleh Pj. Kepala Desa Sukarame dan telah terdaftar dikantor Camat kualuh hulu kabupaten Labuhan Batu Reg. Nomor 593/205/Pem/2008 tanggal 8 juli 2008, beserta lengkap dengan lampiran asal muasal tanah seluas $40.000 \mathrm{M}^{2}(4 \mathrm{Ha})$ atas nama Sri Rezeki Siti Sukasih (ic.Penggugat III), Selanjutnya diberi tanda P-5; Sehingga benar bahwa Tanah yang didalilkan oleh Penggugat adalah Tanah yang berbeda dengan tanah milik sitergugat.

5. Menimbang, bahwa luas tanah dan lokasi tanah yang digugat para penggugat berbeda dengan luas dan lokasi tanah yang saat ini tergugat kuasai dan usahai, dalam artian berbeda lokasi yaitu Dusunnya, Desa dan Kecamatannya, dan Luasnya 6,3 Ha kontra 28.

6. Menimbang, bahwa kuasa tergugat-I mendalilkan bahwa tergugat I tidak pernah menguasai dan mengusaha tanah kebun di Dusun Lubuk Pinang Desa 
Media Komunikasi dan Informasi Hukum dan Masyarakat

Sukarame Kecamatan Kualuh Hulu kabupaten Labuhan Batu Utara milik para penggugat seluas $28 \mathrm{Ha}$, akan tetapi benar tergugat ada menguasai dan mengusahai lahan kebun seluas 6,3 $\mathrm{Ha}$ yang terletak d Dusun Sidumolyo Desa Air Hitam Kec. Kualuh Leidong Kab. Labuhan Batu Utara.

7. Menimbang, bahwa dengan demikian tergugat-I tidaklah dapat dikatakan sebagai pengguna lahan tanpa izin yang beritikad baik, sehingga majelis hakim berpendapat penggugat dapat membuktikan dalil-dalil gugatannya dan menolak bantahan dari tergugat-I Menimbang, bahwa dengan terbuktinya dalil-dalil dari penggugat, maka bukti-bukti surat selebihnya tidak perlu dipertimbangkan lebih lanjut.

8. Menimbang, bahwa berhubung gugatan ini cukup Kuat dan beralasan maka patut nantinya putusan dijalankan dengan serta merta (uit Voerbaar bij voorraad) walau ada perlawanan banding maupun kasasi.

B. Penyelesaian Sengketa Hak Milik Atas Tanah Melalui Gugatan MelawanHukum di Pengadilan Negeri Rantau Parapat

Mediasi adalah proses penyelesian sengketa dengan perantara pihak ketiga, yakni pihak yang memberi masukan-masukan kepada para pihak untuk menyelesaikan sengketa. Berbeda dengan arbitrase keputusan arbiter atau majelis arbitrase harus ditaati oleh para pihak, layaknya keputusan Pengadilan. Sedangkan mediasi, tidak terdapat kewajiban dari masing-masing pihak untuk menaati apa yang disarankan oleh mediator. ${ }^{22}$ Pasal 1 angka 1 Perma No. 01 tahun 2016 menyatakan bahwa mediasi adalah cara penyelesaian sengketa melalui proses perundingan untuk memperoleh kesepakatan para pihak dengan dibantu oleh Mediator. Mediasi yang dilakukan oleh para pihak dengan bantuan Mediator bertujuan untuk mencapai kesepakatan kedua belah pihak yang saling menguntungkan dan memuaskan bagi para pihak yang bersengketa, dan tidak untuk mencari kalah dan menang. Tahap-tahap perdamaian yang dilakukan oleh Pengadilan melalui lembaga Mediasi sesuai dengan Peraturan Mahkamah Agung Nomor 1 Tahun 2008 yang diperbaharui dengan PERMA Nomor 1 Tahun 2016 tentang Prosedur Mediasi di Pengadilan adalah sebagai berikut:

1. Tahap Pra Mediasi, pada hari sidang yang ditentukan dan dihadiri oleh kedua belah pihak yang berperkara, Hakim mewajibkan para pihak memberikan kuasa kepada kuasa hukum, maka setiap Keputusan yang diambil oleh kuasa hukum, wajib memperoleh persetujuan tertulis dari para pihak. Agar kesepakatan yang diambil oleh kuasa hukum benar-benar merupakan kehendak para pihak. Pada hari itu juga paling lama 2 hari kerja berikutnya para atau kuasa hukum mereka wajib berunding untuk memilih Mediator dengan alternatif pilihan, Ialu menyampaikan Mediator pilihan kepada Ketua Majelis, jika tidak bersepakat maka para pihak wajib memilih Mediator dari daftar Mediator yang disediakan oleh Pengadilan Negeri, dan jika hal ini juga tidak disepakati oleh para pihak, maka Ketua Majelis yang akan merujuk Mediator

22 Jimmy Joses Sembiring, 2011, Cara Menyelesaikan Sengketa di Luar Pengadilan, Jakarta:Visimedia, hlm 28. 
Media Komunikasi dan Informasi Hukum dan Masyarakat

dari daftar Mediator dengan suatu penetapan.

2. Tahap Mediasi, penunjukan Mediator para pihak diberi waktu paling lama lima hari kerja, para pihak dapat menyerahkan resum perkara kepada satu sama lain dan kepada Mediator. Mediator selanjutnya menentukan jadwal pertemuan, dimana para pihak dapat didampingi kuasa hukumnya.

Proses Mediasi pada dasarnya bersifat rahasia dan berlangsung paling lama tiga puluh hari kerja sejak pemilihan atau penetapan penunjukan Mediator dan dapat di perpanjang paling lama empat belas hari kerja sejak berakhir masa tiga puluh hari tersebut dengan syarat bahwa kesepakatan akan tercapai. Apabila di dalam Mediasi tercapai kesepakatan, maka para pihak dengan bantuan Mediator wajib merumuskan secara tertulis kesepakatan yang diacapai dan di tandatangani oleh para pihak dan Mediator. Hakim kemudian mengukuhkan kesepakatan tersebut sebagai suatu akta perdamaian. Tahapan mediasi ini para pihak hanyalah menjalankan hasil-hasil kesepakatan, yang telah mereka tuangkan bersama dalam suatu perjanjian tertulis. Kesepakatan yang di buat para pihak harus memenuhi beberapa persyaratan yaitu: "Kesepakatan perdamaian berbentuk tertulis, pihak yang membuat kesepakatan perdamaian adalah pihak yang mempunyai kekuasaan serta seluruh pihak yang terlibat dalam perkara ikut dalam persetujuan perdamian". ${ }^{23}$

Selanjutnya, ada (3) Tahap implementasi hasil mediasi, tahap ini merupakan tahap

${ }^{23}$ M. Yahya Harahap, 2011, Hukum Acara Perdata Tentang Gugatan, Persidangan, Penyitaan, Pembuktian dan Putusan Pengadilan, Jakarta: Sinar Grafika, hlm 229. dimana para pihak hanyalah menjalankan hasilhasil kesepakatan yang telah mereka tuangkan bersama dalam suatu perjanjian tertulis. Para pihak menjalankan hasil kesepakatan berdasarkan komitmen yang telah mereka tunjukkan selama dalam proses Mediasi. Pelakasanaan dari hasil mediasi pada umumnya dilakukan oleh para pihak sendiri tetapi tidak tertutup kemungkinan juga ada bantuan pihak lain untuk mewujudkan kesepakatan atau perjanjian tertulis. Keberadaan pihak lain disini hanyalah sekedar membantu menjalankan hasil kesepakatan tertulis,setelah pihak lain mendapatkan persetujuan dari kedua belah pihak. Apabila di dalam Mediasi tercapai kesepakatan, maka para pihak dengan bantuan Mediator wajib merumuskan secara tertulis kesepakatan yang diacapai dan ditandatangani oleh para pihak dan Mediator.

Hakim kemudian mengukuhkan kesepakatan tersebut sebagai suatu akta perdamaian. Tahapan mediasi ini para pihak hanyalah menjalankan hasil-hasil kesepakatan, yang telah mereka taungkan bersama dalam suatu perjanjian tertulis. Gugatan merupakan suatu perkara yang mengandung sengketa atau konflik anatara pihak-pihak yang menuntut pemutusan dan penyelesaian pengadilan. Gugatan adalah tuntutan hak yaitu tindakan yang bertujuan memberikan perlindungan yang diberikan oleh pengadilan untuk mencegah perbuatan main hakim sendiri. Menurut penulis gugatan adalah suatu permohonan yang disampaikan kepada ketua Pengadilan Negeri yang berwenang, mengenai suatu tuntutan terhadap pihak lainnya, dan harus diperiksa menurut tata cara tertentu oleh pengadilan, serta kemudian diambil putusan terhadap gugatan tersebut. 
Media Komunikasi dan Informasi Hukum dan Masyarakat

Berdasarkan pendapat di atas dapat diketahui bahwa gugatan adalah suatu permohonan atau tuntutan hak yang disampaikan kepada Pengadilan yang berwenang terhadap pihak lain agar diperiksa sesuai dengan prisip keadilan terhadap gugatan tersebut. Ketika sebuah gugatan sampai didepan siding pengadilan, maka disitu selalu ada pihak penggugat, tergugat dan perkara yang disengketakan. Proses penyelesaian sengketa melalui gugatan dalam kasus perbuatan melawan hukum dalam sengketa kepemilikan tanah di Pengadilan Negeri Rantau Prapat dilakukan dengan tahapan-tahapan sebagai berikut: Langkah pertama yaitu dengan melakukan pendaftaran gugatan tersebut ke Pengadilan.

Registrasi perkara dilakukan setelah dilakukanya pembayaran panjar biaya perkara. Bagi gugatan yang telah diajukan pendaftarannya ke Pengadilan Negeri Rantau Prapat, Pelimpahan tersebut harus dilakukan secepat mungkin agar tidak melanggar prinsipprinsip penyelesaian perkara secara sederhana, cepat dan biaya ringan, selambatlambatnya 7 hari dari tanggal registrasi. Kemudian adanya penetapan Majelis Hakim oleh Ketua Pengadilan Negeri Rantau Prapat, setelah Ketua Pengadilan Negeri Rantau Prapat memeriksa berkas perkara yang diajukan Panitera, kemudian Ketua Pengadilan Negeri Rantau Prapat menetapkan Majelis Hakim yang akan memeriksa dan memutus perkara. Penetapan itu harus dilakukan oleh Ketua Pengadilan Negeri Rantau Prapat selambatlambatnya 7 hari setelah berkas perkara diterima oleh Ketua Pengadilan Negeri Rantau Prapat. Majelis Hakim yang akan memeriksa dan memutus perkara tersebut terdiri dari sekurang-kurangnya 3 orang hakim, dengan komposisi 1 orang Ketua Majelis Hakim dan 2 lainnya Hakim Anggota.

Setelah itu adanya penetapan hari sidang dan Majelis Hakim terbentuk, Majelis Hakim tersebut kemudian menetapkan hari sidang. Penetapan itu dituangkan dalam surat penetapan. Penetapan itu dilakukan segera setelah Majelis Hakim menerima berkas perkara. Setelah hari sidang ditetapkan, selanjutnya Majelis Hakim memanggil para pihak (Penggugat dan Tergugat) untuk hadir pada hari sidang yang telah ditentukan. Peneliti mencermati bahwa pertimbangan Hakim dalam memutuskan perkara gugatan perbuatan melawan Hukum tentang Hak Milik Atas Tanah dalam Perkara Perdata Putusan Pengadilan Negeri RantauPrapat Nomor putusan 55 Pdt. G.2007/PN.RAP Adapun dasar dari gugatan Penggugat adalah sebagai berikut:

1. Alasan gugatan Penggugat adalah perbuatan melawan hukum yaitu adanya perbuatan melawan hukum yang dilakukan oleh Tergugat karena melakukan pengushaan lahan oleh bukan pemilik tanpa ada persetujuan atau izin dari Pemilik.

2. Tuntutan Penggugat kepada Tergugat adalah pengosongan objek sengketa dan tuntutan ganti rugi baik materiil maupun immateriil.

3. Gugatan Penggugat adalah jelas dan terang benderang baik mengenai alas gugatnya, positanya, maupun petitumnya, sehingga gugatan Penggugat adalah jelas, tidak kabur atau tidak Obscuur Libel.

4. Penggugat telah memenuhi Pasal 12 Ayat (2) Undang- Undang No.4 Tahun 1992, yaitu mengenai penghunian Lahan tanpa hak, maka Tergugat jelas bersalah dan harus membayar ganti kerugian. Kemudian, 
Media Komunikasi dan Informasi Hukum dan Masyarakat

5. Hakim sudah sudah sepantasnya mempertimbangan alat bukti yang di ajukan oleh tergugat berupa sertifikat tanah yang di keluarkan oleh kepala desa Kualuh Ledong dengan alas dasar Surat Keterangan Kepemilikan Tanah yang dikeluarkan oleh Kepala Desa Air Hitam Nomor : 593.2/KL/2012 yang diterbitkan januari 2012

6. Hakim tidak sepantasnya menjatuhkan hukuman kepada pihak Tergugat karena jelas dan terbukti sertifikat tanah yang dilampirkan sah dikeluarkan oleh kepala desa kualuh ledong. Kemudian Hakim sudah pantas menjatuhkan hukuman yang tidak kabur dan mempunyai kekuatan hukum tetap, sehingga pihak Tergugat tidak puas terhadap isi putusan yang dijatuhkan hakim, maka Tergugat mempunyai hak untuk melakukan upaya hukum lain yaitu Banding maupun Verset terhadap putusan yang telah dilaksanakan.

7. Hakim Ketua Pengadilan Negeri Rantau Prapattidak pantas menjatuhkan putusan dengan dasar bahwa perbuatan melawan hukum, Pasal 1365 BW“ Tiap perbuatan melawan hukum, yang membawa kerugian kepada seseorang yang lain, mewajibkan orang yang karena salahnya menerbitkan kerugian itu, mengganti kerugian tersebut".Selanjutnya,

8. Gugatan Penggugat adalah telah jelas baik mengenai alas gugatnya, positanya, maupun petitumnya, sehingga gugatan Penggugat tidak kabur atau tidak Obscuur Libel, maka Eksepsi Tergugat adalah tidak berlasan menurut hukum, dan oleh karennya Eksepsi Tergugat harus dinyatakan ditolak untuk seluruhnya.
9. Hakim Ketua Pengadilan Rantau Prapat terhadap Tanaman Sawit milik Tergugat Dan dasar hukum Hakim Ketua sudah pantas dan mencapai kerugian materiil selama 9 tahun sebanyak Rp. 640.000 .000 (Enam Ratus empat puluh juta) akibat hunian dan usaha tanaman dari sitergugat dengan sertifikat ganda.

C. Akibat Hukum dari Putusan Hakim mengenai Hak Milik Atas Tanah Pada Obyek yang sama di Pengadilan Negeri Rantau Prapat.

Akibat hukum yang muncul setelah putusan Pengadilan Negeri Rantau Prapat dibacakan, maka putusan tersebut mempunyai kekuatan hukum tetap dan mampunyai akibat terhadap para pihak yang bersengketa. Akibat hukum dari putusan tersebut adalah pihak yang kalah harus mau melaksanakan isi putusan dengan suka rela. Dalam hal ini pihak yang kalah adalah Tergugat, apabila pihak Tergugat tidak puas dengan putusan Pengadilan Negeri Rantau Prapat dapat melakukan upaya hukum lain yaitu Banding, Kasasi dan Peninjauan Kembali. Akibat hukum terhapat para pihak yang berpekara adalah pelaksanaan putusan. Semua orang yang bersengketa, apabila sudah mempunyaiPutusan yang berkekuatan hukum tetap, maka wajib melaksanakan putusan tersebut, kalau tidak ada lagi upaya hukum lain. Apabila pihak yang kalah pihak Tergugat tidak mau melakukan tindakan hukum yang lain, maka yang menang adalah pihak Penggugat.

D. Analisis Kewenangan Kepala Desa Sebagai PPAT Sementara sebagai dasar alat bukti tergugat

Kedudukan hukum kepala desa dalam mengeluarkan surat keterangan tanah milik dasar hukum sesuai ketentuan pasal 24 ayat 2 PP No.24 tahun 1997 tentang pendaftaran 
Media Komunikasi dan Informasi Hukum dan Masyarakat

tanah yang menyebutkan bahwa, "terhadap bidang tanah yang berasal dari hak hak lama untuk dapat didaftarkan hak atas tanahnya di kantor Pertanahan maka kepala Desa memiliki kewenangan untuk menerbitkan surat keterangan sebagai alat bukti dalam Tanah Pelaksanaan pendaftaran untuk memperoleh sertifikat hak atas tanah dikantor pertanahan tempat dimana tanah tersebut berada.disamping itu dalam peraturan Mentri Dalam Negri No.6 Tahun 1972 tentang Pelimpahan Wewenang Pemberian Hak Atas Tanah pada ketentuan Pasal 11 Menyatakan Bahwa Kepala Kecamatan Dapat memberikan Izin pembukaan tanah dengan luas \pm 2 Hektar dengan memperhatikan pertimbangan kepala desa tempat dimana tanah tersebut berada.

Pertimbangan Hukum majelis Hakim Pengadilan Negeri Rantau Prapat Nomor putusan 55 Pdt. G.2007/PN.RAP Tidak sesuai atau bertentangan dengan ketentuan Hukum yang berlaku dibidang Pertanahan dimana HakHak Salmon Siregar sebagai pemilik tanah yang sah diperoleh dari hasil pembagian tanah yang belum memiliki Sertifikit Hak Milik Atas Tanah dikarenakan Tanah tersebut Kawasan Hutan Lindung dan dibagikan Keseluruh Masyarakat Kualuh Ledong dengan alas dasar Surat Keterangan Kepemilikan Tanah yang dikeluarkan oleh Kepala Desa Air Hitam Nomor : 593.2/KL/2012 yang diterbitkan januari 2012 Secara jelas di Abaikan oleh Majelis Hakimdan tidak memperoleh perlindungan hukum semestinya dari aparat penegak hokum khususnya pihak pengadilan. Hak hak pemohon sitergugat dalam Pengadilan Negeri Rantau Prapat Nomor putusan 55 Pdt. G.2007/PN.RAP dalam hal diberikannya Prioritas Pertama, untuk mendaftarkan tanah yang dibelinya secara sah berdasarkan surat keterangan tanah yang dikeluarkan kepala desa untuk memperoleh sertifikat hak atas tanah tersebut tidak memperoleh perlindungan dari putusan pengadilan tersebut. Oleh karena itu putusan Pengadilan itu bertentangan dengan nilai-nilai kepatutan nilai yang adil dalam masyarakat karena tidak sesuai dengan ketentuan ketentuan hukum yang berlaku di bidang pendaftaran tanah di Indonesia.

\section{Kesimpulan}

1. Gugatan adalah suatu permohonan atau tuntutan hak yang disampaikan kepada Pengadilan yang berwenang terhadap pihak lain agar diperiksa sesuai dengan prisip keadilan terhadap gugatan tersebut. Ketika sebuah gugatan sampai didepan sidang pengadilan, maka disitu selalu ada pihak penggugat, tergugat dan perkara yang disengketakan.

2. pelaksanaan pendaftaran tanah yang melahirkan sertifikat tersebut dilakukan secara sah, artinya sesuai dengan ketentuan perundang-undangan yang berlaku, sebagai contoh bahwa salah satu tahapan dalam pelaksanaan pendaftaran tanah adalah dilakukan pengumuman terhadap data tanah yang telah diteliti sebelum dilakukan pembukuan hak atas tanah. Apabila pengumuman tidak dilakukan atau dilakukan tidak sesuai dengan aturan atau menyimpang dari tujuan diadakan pengumuman maka hal itu dapat dikategorikan sebagai cacat hukum dalam proses pensertifikatan.

3. Pertimbangan Hukum majelis Hakim Pengadilan Negeri Rantau Prapat Nomor putusan 55 Pdt. G.2007/PN.RAP Tidak sesuai atau bertentangan dengan ketentuan 
Media Komunikasi dan Informasi Hukum dan Masyarakat

Hukum yang berlaku dibidang Pertanahan dimana Hak-Hak Salmon Siregar sebagai pemilik tanah yang sah diperoleh dari hasil pembagian tanah yang belum memiliki Sertifikat Hak Milik Atas Tanah dikarenakan Tanah tersebut Kawasan Hutan Lindung dan dibagikan Keseluruh Masyarakat Kualuh Ledong dengan alas dasar Surat Keterangan Kepemilikan Tanah yang dikeluarkan oleh Kepala Desa Air Hitam Nomor : 593.2/KL/2012 yang diterbitkan januari 2012 Secara jelas di Abaikan oleh Majelis Hakim dan tidak memperoleh perlindungan hukum semestinya dari aparat penegak hukum khususnya pihak pengadilan. Hak hak pemohon sitergugat dalam Pengadilan Negeri Rantau Prapat Nomor putusan 55 Pdt. G.2007/PN.RAP dalam hal diberikannya Prioritas Pertama, untuk mendaftarkan tanah yang didapatnya secara sah berdasarkan surat keterangan tanah yang dikeluarkan kepala desa untuk memperoleh sertifikat hak atas tanah tersebut tidak memperoleh perlindungan dari putusan pengadilan tersebut. Oleh karena itu putusan Pengadilan itu bertentangan dengan nilai-nilai kepatutan nilai yang adil dalam masyarakat karena tidak sesuai dengan ketentuan ketentuan hukum yang berlaku di bidang pendaftaran tanah di Indonesia.

\section{DAFTAR PUSTAKA}

\section{A. Buku Buku}

Adrian Sutedi, Peralihan Hak Atas Tanah Dan Pendaftarannya, Sinar Grafika, Jakarta, 2009

Aminuddin Salle (Dkk, Buku Bahan Ajar: Hukum Agraria, Makassar Aspublihing), 2011

Boedi Harsono, Hukum Agraria Indonesia, Sejarah Pembentukan Undang-Undang Pokok Agraria, Isi dan Pelaksanaannya, cetakan kesepuluh, Djambatan, Jakarta, 2005

Farida Patittingi, Dimensi Hukum Pulau-Pulau Kecil Di Indonesia, Rangkang Education, Yogyakarta, 2012

Irawan Soerodjo, Kepastian Hukum Hak Atas Tanah Di Indonesia, Arkola, Surabaya, 2003

Jimmy Joses Sembiring, Cara Menyelesaikan Sengketa di Luar Pengadilan, Visimedia, Jakarta : 2011

Kartini Muljadi dan Gunawan, Hak-Hak Atas Tanah, Jakarta: Kencana, 2008

M. Yahya Harahap, Hukum Acara Perdata Tentang Gugatan, Persidangan, Penyitaan,Pembuktian dan Putusan Pengadilan, Jakarta: Sinar Grafika, 2011

Miethra Tanjung, Skripsi : "Kedudukan Kepala Desa Mengeluarkan Surat Keterangan Tanah Dalam Transaksi Jual Beli Tanah Ditinjau Dari Peraturan Pemerintah Nomor 24 Tahun 1997 Tentang Pendaftaran Tanah" (Bengkulu : Universitas Bengkulu, 2014)

Muhammad Syaifuddin, Hukum Kontak : Memahami Kontrak Dalam Perspektif Filsafat, Teori, Dogmatik, Dan Praktik Hukum (Seri Pengayaan Hukum Perikatan), CV. Mandar Maju, Bandung, 2012

Risnarto, Dampak Sertipikasi Tanah Terhadap Pasar Tanah dan Kepemilikan Tanah Skala Kecil, Makalah disajikan pada Seminar Nasional Land and Household Economy 1970-2007, Changing Roads for Poverty Reduction. PSEKP and 
Media Komunikasi dan Informasi Hukum dan Masyarakat

UNESCAP-CAPSA, Bogor.Indonesia, tanggal 25 Juni 2007

Soerjono Soekanto, Pengantar Penelitian Hukum, UI-PERSS, Jakarta, 1982

Urip santoso, Pendaftaran Dan Peralihan Hak Atas Tanah, Kencana, Jakarta, 2011

Teguh Samudra, Hukum Pembuktian Dalam Acara Perdata, Alumni, Bandung, 2004

Wantijk Saleh, Hak Anda Atas Tanah, Ghalia Indonesia, Jakarta, 1982

\section{B. Website}

Klinik Hukum Online, "Surat Kepemilikan Tanah atau Surat Keterangan Riwayat Tanah", 2017 http://www.hukumonline.com/klinik/detail/t591d5 3cb37b54/surat-kepemilikan-tanah-atau-suratketerangan-riwayat-tanah, [05/06/2018]

\section{Perundang-undangan}

Kitab Undang-Undang Hukum Perdata

Peraturan Menteri Dalam Negri No.6 Tahun 1972 tentang Pelimpahan Wewenang Pemberian Hak Atas Tanah

Peraturan Menteri Negara Agraria/Kepala BPN Nomor 3 Tahun 1999 tentang Pelimpahan Kewenangan Pemberian dan Pembatalan Keputusan Pemberian Hak Atas Tanah Negara

Peraturan Pemerintah Republik Indonesia No. 24 Tahun 1997 Tentang Pendaftaran Tanah

Peraturan Pemerintah No.38 Tahun 1963 Tentang Penunjukan Badan-Badan Hukum Yang Dapat Mempunyai Hak Milik Atas Tanah

Peraturan Pemerintah Nomor 10 tahun 1961 Tentang Pendaftaran Tanah

Peraturan Presiden Nomor 10 Tahun 2006 tentang Badan Pertanahan Nasional Undang-Undang Dasar 1945

Undang-Undang No. 5 Tahun 1960 Tentang Peraturan Dasar Pokok-Pokok Agraria 